\title{
An Overview of the Agricultural Extension System in Egypt: The History, Structure, Modes of Operation and the Future Directions
}

\author{
Ahmed M. Diab ${ }^{1}$, Mohamed Yacoub ${ }^{2}$ \& Mohamed H. AbdelAal ${ }^{3}$ \\ ${ }^{1}$ Department of Rural Sociology and Agricultural Extension, Faculty of Agriculture, New Valley University, \\ El-Kharga, Egypt \\ ${ }^{2}$ Higher Institute for Agricultural Cooperation (HIAC), Ministry of Higher Education, Cairo, Egypt \\ ${ }^{3}$ Department of Rural Sociology and Agricultural Extension, Faculty of Agriculture, Cairo University, Cairo, \\ Egypt \\ Correspondence: Ahmed M. Diab, Department of Rural Sociology and Agricultural Extension, Faculty of \\ Agriculture, New Valley University, El-Kharga, Egypt. Tel: 20-100-130-6492. E-mail: a.diab@aun.edu.eg
}

Received: July 18, 2020 Accepted: August 14, 2020 Online Published: August 26, 2020

doi:10.5539/sar.v9n4p30 URL: https://doi.org/10.5539/sar.v9n4p30

\begin{abstract}
The main purpose of the current manuscript is to review the agricultural extension system in Egypt. The information gleaned in this article could be useful for policymakers, extension administrators, and extension researchers to identify ways for improving educational services of devising training programs for audience and agents, approaches of farmers' participation, and schemes of policy development. More specifically the objectives of this study are to review the Egyptian agricultural extension system in terms of the: 1) the history of the Egyptian agricultural extension system, 2) the organizational structure of the Egyptian extension system, 3) types of agricultural extension and program delivery mechanisms in Egypt, 4) current situation of the Egyptian agricultural extension system, and 5) the possible future direction for the Egyptian agricultural extension system. A comprehensive review of gray literature was conducted to identify characteristics of the agricultural extension system in Egypt, relevant documents used including, foundation legislation, review and analysis of literature of international organizations as well as peer reviewed journal articles. The extension history, structure, and modes of operation were discussed, and the future directions were concluded.
\end{abstract}

Keywords: agricultural extension, Egypt, review, SWOT, logical frame analysis

\section{Introduction and Objectives}

The use of the word "extension" derived from the educational development in England during the second half of the nineteenth century. Around 1850, discussions began in the two ancient universities of Oxford and Cambridge about how they could serve the educational needs of the rapidly growing populations in the industrial, and urban area near their homes. Just before 867 that a first practical attempt was made in what was designated as 'university extension' but the activity developed quickly to become a well-established movement before the end of the century (Swanson, et al., 1997).

Exchange of information especially on farming is an innate human behavior; however, formal extension in most countries did not start until the late 1800s AD. The first modern extension service was started in Ireland during the potato famine in 1845 (Swanson et al. 1997). In the United States and Canada, formal extension started during the late 1800s. France began its national service in 1879 using itinerant agriculturists; Japan and many of the British colonies also started extension services during that time (Anandajayasekeram, et al., 2008).

Addressing the new and the ever-growing challenges in agriculture requires extension service to play an expanded role with diverse objectives. Equally important, extension service is an essential pillar for both the rural community progress and as a part of the agricultural research and development strategy. It helps in the generation and dissemination of useful information and practical application of knowledge in the agriculture sector (Kumara and Geetha, 2016).

The era of structural reform imposed a question mark about the public spending on agriculture, chiefly, spending on agricultural extension services. More interest was given to outsourcing alternatives including Public-Private Partnership (PPP). Even though, the public budjet has been diminishing constantly, or the calls of PPPs, the 
"Public sector commitment should remain essential to the promotion of agricultural extension and communication for rural development and food security" (Rivera and Qamar, 2003).

The economies of most developing countries are dependent on rural based small-scale agriculture whose productivity is not increasing (in some cases, even declining) contributing towards household food insecurity, malnutrition and poverty. This situation has been attributed to number of factors, one of which has been inappropriate and/or ineffective dissemination of technologies (Anandajayasekeram, et al., 2008).

The agriculture sector plays a critical role in the Egyptian economy with a growth rate estimated at $3.2 \%$ and contributes to 14.5 percent of the GDP and employs 25.6\% of total employment (CAPMAS, 2018). Agriculture employs almost $45 \%$ of all women in the workforce (USAID, 2017). Most of the farming activities in Egypt are dominated by small scale farmers with an average size of less than one feddan (one feddan $=4200 \mathrm{~m}^{2}$ ). The small-scale family farming represents 24.23 million people working in the agriculture sector or $57 \%$ of the rural population where each small family farm feeds a family of average of 6 persons (Marzin, et al., 2017).

During the last four decades, public Extension organization has been experiencing massive structural and functional -mostly negative- changes, which call for a deep investigation of the structure, and the functions to add more attention to the future directions of the Egyptian extension service.

The main purpose of the current manuscript is to review the agricultural extension system in Egypt. The information gleaned in this article could be useful for policymakers, extension administrators, and extension researchers to identify ways for improving educational services and devising training programs for audience and agents, approaches of farmers' participation, and schemes of policy development.

More specifically, the objectives of this study are to review the Egyptian agricultural extension system in terms of the:

1. The history of the Egyptian agricultural extension system,

2. The organizational structure of the Egyptian agricultural extension system,

3. Types of agricultural extension and program delivery mechanisms in Egypt,

4. Current situation of the Egyptian agricultural extension system, and

5. The possible future direction for the Egyptian agricultural extension system

\section{Methodology}

A comprehensive review of gray and commercially published literature was conducted to identify characteristics of the agricultural extension system in Egypt, relevant documents used, including foundation legislation, review and analysis of literature of international organizations reports as well as peer reviewed journal articles.

A SWOT analysis of the extension environment conducted by a panel of experets of Agricultural extension, moderated and edited by one of the authores (M. Abdelaal). A Logical Frame Analysis (LFA) of the main challenges/issues that are facing the egyptian agricultural extension system, basd on SWOT findings was constructed

\section{Results}

\subsection{History of the Agricultural Extension System in Egypt}

After the wide application of land reform interventions by the 1952 revolution, and in order to improve farm productivity at a small scale farm, the government of Egypt established the Egyptian Agricultural Extension Service (EAES) in late 1953, which consisted -at that time- at the central level of four main branches: 1) Programs and training; 2) Technical services; 3) Agricultural units and demonstrations fields; and 4) Agricultural cooperatives and rural organizations services. It worth to mention, EAES had been changing in many phases as follows:

\subsubsection{The Period from 1958-1962}

This period has witnessed an alteration in the organizational structure by which the EAES was moved to be affiliated to the General Directorate for Regional Services instead of the Agricultural Awareness Department.

\subsubsection{The Period from 1963-1964}

The affiliation of the EAES under the General Directorate of Regional Services was abolished, and a new organizational structure named the "General Directorate of Agricultural Extension and Training" (GDAET) has emerged within the Ministry of Agriculture. 


\subsubsection{The Period from 1964-1968}

The "General Directorate of Agricultural Extension- GDAE" was established and the training functions were included under the newly established GDAE.

\subsubsection{The Period from 1968-1976}

A new ministisial decree was issued to establish undersecretary of Ministry for Agricultural Extension Affairs, the General Directorate of Agricultural Extension became annex directly to the -newly founded- undersecretary.

\subsubsection{The Period from 1976-1979}

This period didn't witness any organizational changes at the central level, nonetheless, significant changes took place at all subordinate levels, governorate, district, and village levels, and so agricultural extension agent were installed in each village of rural Egypt.

\subsubsection{The Period from 1979-1983}

The agricultural extension service was rearranged by the Ministerial Resolution No. 151/1979, which defined the main function of GDAE developing plans to maximiz the agricultural production through the educational efforts that guide farmers and their families to solve their problems and encourage them to adopt recommendations of agricultural research. From that time and so forth, the agricultural extension organization became administratively linked to the research under the umbrella of the Agricultural Research Center (ARC).

\subsubsection{In the Year 1988}

The organizational structure of agricultural extension had changed from the GDAE to the Central Administration for Agricultural Extension and Environment (CAAEE), which refers to recognition and a higeir position of Agricultural Extension in the structure of MALR.

\subsubsection{In 1993}

Specialized extension services were adopted to provide the services (by the Subject Matter Specialist "SMS", he/she is an expert in particular crop, assumed to receive well, focused, and continous training under the technical supervision of the CAAEE) according to the crop rotation and under the technical supervision of the CAAEE.

\subsubsection{In the Year 2000}

The Ministerial Decree No. 1833 was issued, by which seven guiding regional administrations were initiated: (North Delta, West Delta, North-Central Delta, East Delta, South-Central Delta, Upper Egypt, North Coast) each administration is linked with the ARC research station of the same region and provides services to the governorates located in that region.

\subsection{Current Organizational Structure of the Agricultural Extension System in Egypt}

MALR function was reformed to get rid of commercial activities and limit its function to cover only 7 sectors. One of these sectors is the Agricultural Extension Sector (AES). The AES was established and comprised of four central administrations namely: 1) The Central Administration for Horticulture and Field Crops, 2) The Central Administration for Afforestation, Nurseries, and Environment, 3) The Central Administration for Soils and water, and 4) The CAAEE. Nonetheless, not all these administrations provide extension-based services.

More importantly, CAAEE structure was inconsistent as a result of the trajectory administrative shift during the 1990s when a ministerial decree was issued by which CAAEE moved to be affiliated "technically" to the ARC, to support the Research/Extension linkage. At the same time, CAAEE remained "administratively" affiliated to AES. This situation created double lines of command. Figure 1 presents the four administrations consisting the structure of AES. 


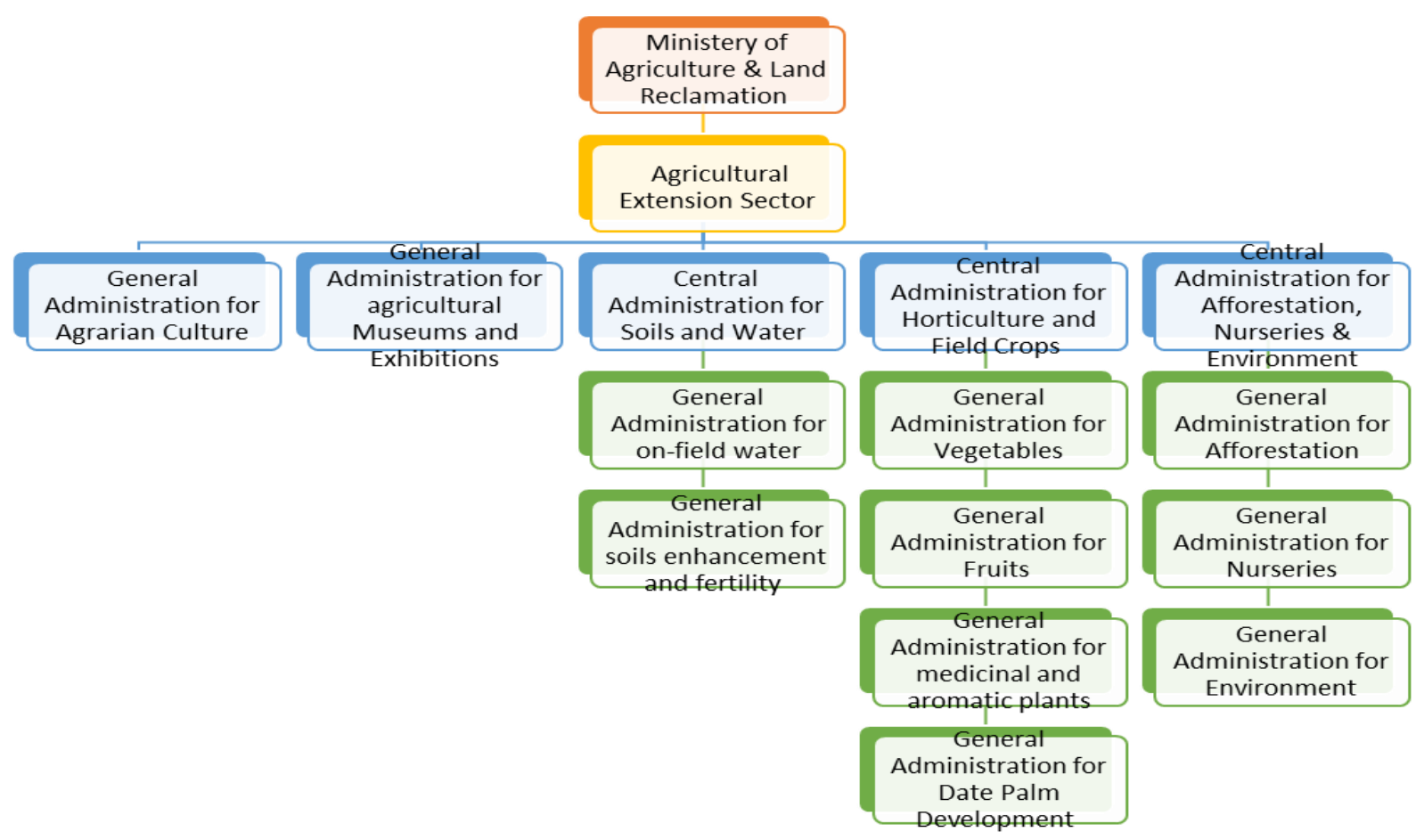

Figure 1. The current structural hierarchy of the agricultural extension sector within the Ministry of Agriculture and Land Reclamation, Egypt

Source: http://www.agr-egypt.gov.eg/

The structure of CAAEE is composed of eighteen departments all of them deal with the extension work e.g. preparation, planning, implementation, and evaluation in a specific filed; namely, animal production, horticulture, cotton \& fibers, sugar crops, cereals, pulses \& oil crops, crops of newly reclaimed lands, agriculture extension programs, extension publications, media, marketing, agriculture councils, extension units, extension centers, rural development, financial $\&$ administrative affairs, technical office, and information technology (CAAEE, 2018a).

The current structure of the extension organization is replicated at all administrative levels, starting from the CAAEE at the central level, and then at Directorates of Agriculture at the Governorate level and it's affiliating District levels down to the village level (See Figure 2).

The extension service at the governorate level is supervised by the Directorate of Agriculture. Governorate administration includes technical and administrative staff and supervise the extension workers at both district and village levels whereas Village Extension Workers (VEWs) interact with farmers and farming families on almost daily basis. (Abdelhakam, 2005). 

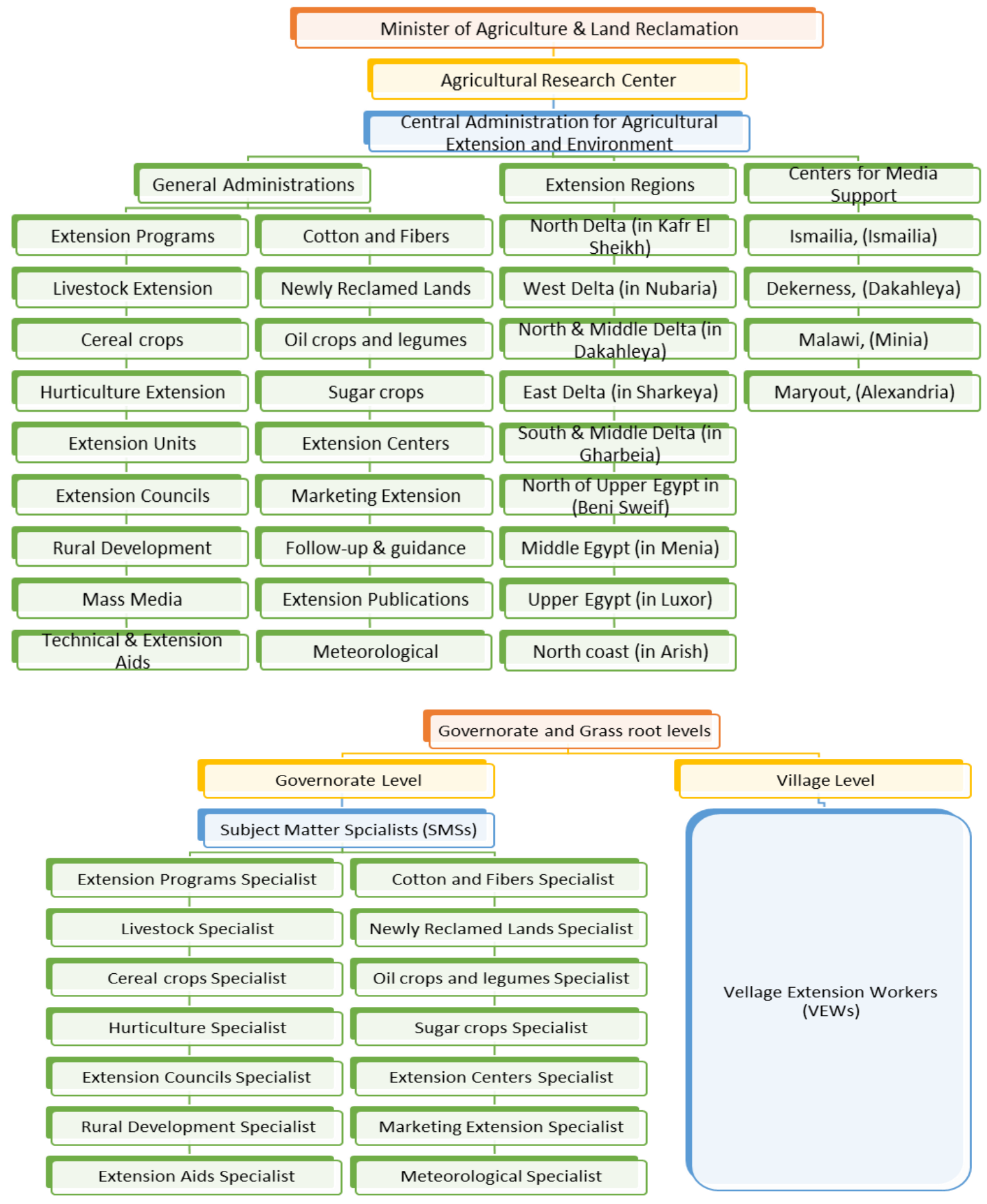

Figure 2. Structural Hierarchy of the Central Administration of Agricultural Extension and Environment in Egypt Source: http://www.caaes.org/

\subsection{Types of Agricultural Extension and Program Delivery Mechanism}

The mechanism of delivery of the services of the public extension system is characterized as being a central "top-down" approach. These services are directed mainly to smallholders. However, an observer can notice more efforts to induce more participatory "bottom-up" mechanisms aiming to design extension programs which are more responsive to farmers' actual needs. Examples of this trend are the extension activities that are based on "Farmers Field Schools (FFSs)", or Farmer to Farmer (FTF). In addition to the public extension service there is 
also an active private sector extension services provided by companies of inputs and other services suppliers, crop-based extension, these private sector extension services are manly targeting big commercial farmers and agricultural export corporation (CAAEE, 2018a).

\subsubsection{Regional Research and Extension Councils (RRECs)}

To develop more responsive, accessible, and local-based extension programs, MALR established (9) nine RREC covering the -previously mentioned- seven geographical regions of Egypt. The main function of each RREC is to make research efforts and provide extension services fit for farmers' needs and the prevailing production patterns (CAAEE, 2018a).

Effective implementation of Extension programs is chiefly based on good communication between researchers, extension agents and farmers. To accomplish this goal, CAAEE utilizes variety of extension teaching methods to accelerate the transfer of new agricultural technologies to different categories of farmers including, but not limited to: On-farm demonstrations, Technical consultation, Field days, Meetings, Home and Farm Visits, Publications, Media, Extension training, Exhibition, and National campaigns (Abdel-Hamid, 1998).

\subsubsection{Development Support and Communication Centers (DSCCs)}

To support extension communication and media production, MALR established four DSCCs. These DSCCs have distributed to serve the main agriculture regions (Ismailia North-East of Delta), (Dikirnis, Middle of Delta), (Maryout, East of Delta), and (Malawi, middle-Upper Egypt). The DSCCs had been established over a period of several years with focus on producing extension teaching and training material and organize extension events inside DSCC facilitates or in the villages in the surrounding governorates. Each of the DSCCs is equipped with audio-video studio, a printing house, and an auditorium and training halls. Some of the centers can provide full board accommodation to the trainees, visitors, and the staff participating in extension campaigns, and rural development programs

\subsubsection{Agricultural Extension Centers (AECs)}

The MALR decided in 1995 to spread the AECs at village level to work as a basic unit of EAES (Shaker et al., 2003). About 210 AECs were established in villages to support and develop the infrastructure of extension work in Egypt, provide extension services at village level, to be a focal point of extension specialists and to improve extension services in general. Each AEC has a director with a group of extension specialists in various fields of agricultural activities, Each center is equipped with furnished training hall for extension meetings, also, facilities of audio-video aids, computers, and a library of pamphlets, magazines, books, videos, and CDs are available too (CAAE, 2019).

AEC plays several roles including planning, supporting, coordination, and education. The Planning Role: is to identify the local community resources and priorities and to plan for the agricultural extension programs. 2) The Supporting Role: is to contribute to solve the agriculture problems and discover rural leaders, 3) The Coordinating Role: is to coordinate among rural organizations inside the local community, and 4) the Educational Role: is to supply farmers with agricultural information and involving them in rural extension programs (Zahran, 1998).

\subsubsection{Rural Development Centers (RDCs)}

Equally important CAAEE established 60 RDCs distributed in the main (mother) villages in 16 governorates. The RDCs are equipped with machinery for dairy production, bakery and agro-processing facilities and for manufacturing of handcraft, with the aim of promoting integrated sustainable development efforts at local levels (CAAEE, 2018a).

\subsubsection{Agricultural publications}

Regarding agricultural publications, there are four periodical agricultural magazines i.e. the Agricultural Extension Magazine, which have been publishied monthly for 64 year and the Agricultural Extension in New Lands Magazine, which have been published for 22 years by the CAAEE. In addition to the Agricultural Newspaper Magazine, which have been published monthly for 73 years and the Agricultural Thought Magazine, which have been published quarterly for 15 years by the General Administration of Agrarian Culture (GAAC) (Diab, 2017).

\subsubsection{Electronic Extension Initiatives}

As a result of cooperation between MALR and the FAO (2000-2002), the Central Laboratory for Agricultural Expert Systems (CLAES) has developed the Virtual Extension and Research Network (VERCON). VERCON connect research and extension institutions and provide extension staff who works in remote areas with access to 
a vast repository of agricultural information and extension material, beside online support.

By 2004-2006, the National Agriculture Research Information Management System (NARIMS) was established as an integrated, bilingual (Arabic/English) web-based platform aimed at capturing and disseminating information about research institutes, researchers, publications, projects, and the national plan of agricultural and veterinary research in Egypt. Such platform has been developed as a result of collaboration between FAO and ARC and building on the existing FAO tools and methodologies (Anon, 2008).

During the period (2004-2008), the Rural and Agricultural Development Communication Network (RADCON) project has taken the VERCON experience to a broader scale, expanding the network with diversified content and a wider range of stakeholders, including farmers' organizations, youth centers, universities, NGOs, and the private sector (Anon, 2008; Qamar, 2005).

\subsubsection{Mobile Extension Initiative}

The Extension Service in Egypt entered the "digital age" through a pioneering initiative for using mobile phones in the Egyptian agricultural extension service. In June 2011 a joint protocol was signed between three entities: MALR, Vodafone Egypt and Quick Serve Company. The project aimed to supply farmers with agricultural news, information and recommendations through mobile SMS. The project also designed to establish a call center at the ARC to provide farmers with access to specialized extension advices. However, Abdel-Ghany (2014 \& 2015); Diab \& Abdel-Rahman (2016) reported that the initiative didn't arrived in real actions since it was announced.

\subsubsection{HORTISUN Initiative}

In 2013-2015, the HORTISUN initiative was launched to strengthen the capacity of MALR in establishing an effective and efficient horticulture sector information support network/system. HORTISUN support small-scale producers and market service providers contributing to rural development (FAO, 2017).

\subsubsection{Agricultural Satellite Channel}

Egyptian agricultural channel [in Arabic pronounced Misr Al-Zeraiya Channel "MAC"] was established and broadcasted on Nilesat: $11227 \mathrm{~V}$, with the main objective of providing farmers with agricultural recommendations, news, and information. Officials in the MALR, assume that having such satellite agricultural channel would compensate the fatal shortages in numbers of VEWs (http://misralzeraya.tv/). Additionally, during the recent decades The Egyptian TV has produced popular episodes entitled "The Secret of the Land", these episodes were widely viewed by people in the rural communities.

\subsection{Situation of the Egyptian Agricultural Extension System}

The public extension of Egypt is widely criticized for having ineffective and irrelevant activities and programs. Moreover, VEWs, being the frontline of the system are suffering several problems manifested in low socio-economic status, low salaries, lack of incentives and promotion opportunities, lack of sufficient educational qualifications and training, insufficient transportation facilities (El-Shafie, 2009; Abdel-Ghany \& Diab, 2013).

These negative images on agricultural extension and much more were eloquently detailed in the Egyptian Strategy for Agricultural Development 2030". The strategy has confirmed that existing extension organization needs reform and development policies for several reasons, including: (a) Ineffective performance of extension personnel, associated with limited resources and ever-decreasing numbers of extension workers, (b) Lack of trust of agricultural producers in extension agents, especially farmers producing highly specialized crops or engaged in sophisticated farming activities, (c) Lack of mutual relationships between research and extension workers in addition to lack of involvement of university staff and technicians in extension work, (d) unfair salaries of extension workers, especially VEWs (MALR, 2009). There is a clear gap between views of extension workers and farmers about service quality provided by extension personnel (Abdel-Ghany and Diab, 2015). Still, the Egyptian extension system is potintial for reform and possible restructuring (Abdel-Ghany \& Diab, 2013).

The majority of the extension workers are about to reach the retirement age. With a scare hiring of fresh graduate extension staff. This situation resulted in inverted pyramid nature of the extension manpower. And so, there is a risk of lack of continuity and inadequate knowledge and experience transfer from one generation to another. Indeed, the total number of agricultural extension staff in Egypt by 2007 was 9658 decreased to 2503 by 2018 indicating that the extension system lost about 74.1 per cent of its manpower within only 10 years (CAAEE, 2018b).

To assess current situation of agricultural extension in Egypt, SWOT analysis was used. SWOT stands for Strengths, Weaknesses, Opportunities, and Threats, and so a SWOT Analysis is a technique for assessing these 
four aspects of the organization. The function of SWOT is to study the internal and external environments of a agricultural extension, through the identification and analysis of the strengths and weaknesses of the organization, and the opportunities and threats to which it is exposed. Findings of SOWT analysis were rechecked by the participants of the paneland crutinized and edited by one of the authors.

Table 1. SOWT analysis of the extension system in Egypt

STRENGTHS:
Convenient number of Extension Centers (220) spread all over
the country

Four (4) Development support Communication Centers (DSCC's) Located in strategic places (Ismailia (east), Marriout (west), Mansoura (delta), Minia (South).

A State-owned Agricultural Extension TV channel

Convenient Infrastructure for printing publications

Qualified research Capacities at the ARC and universities

A heritage of success stories of extension efforts over the past years

\section{WEAKNESS:}

Erosion of the staff composition at all levels Aging of the majority of the staff members and

the continued retirement levels with no replacement

Lack of suitable Agricultural Extension offices at village level

Lack of means of Transport for field work

Lack of Job structure that promotes development

The affiliation of Extension system to the Agricultural Research system.

Lack of clear vision, mission, and strategy for Extension work

Absence of basis for monitoring and evaluating

Extension activities

Lack of clear methodology for planning, implementation, monitoring and evaluation of Extension programs

The extension organization for some time is swinging between restrictive centralization and inactive decentralization.

Lack of finance

\section{OPPORTUNITIES:}

Emerging political awareness and support to Extension work

Common understanding among all parties of the importance of Extension

The challenges which are facing Agricultural development require extension interventions

Existence of many NGOs with experience in Extension work

The willingness of international donors to participate in reforming extension work.

Availability of large numbers of extension specialized graduates

Existence of numbers of farmers/ producers' organizations as well as reforming Cooperatives.

Large numbers of audience of small age farmers looking for advice of new Agricultural knowledge and practice

\section{THREATS:}

The willingness of some parties to takeover related extension infrastructure

Ignoring Extension requirements when allocating budgets

Dispersion of extension activities among several authorities inside and outside the ministry of Agriculture.

Ignoring of Extension component when designing development projects

The Tendency of researchers to assume the tasks of extension agents

Lack of concrete plans for the linkage between research and extension

\subsection{The Possible Future Direction for the Egyptian Agricultural Extension System}

Based on the previous literature, improving the quality of extension organization, management, and services is crucial for achieving growth in the agricultural sector and for integrating small farmers into the supply and exports chains (Abdou, et al., ND; Diab, 2017; Diab 2018a; 2018b).

Agricultural extension continues to be in transition worldwide. Governments and international agencies are advancing structural, financial and managerial to improve extension services. Decentralization, pluralism, cost-sharing, cost recovery, participation of stakeholders in development initiatives and the decisions and resources that affect them - these are some of the elements in extension's current transition (Rivera and Qamar, 2003).

Encouraging Civil Society Organizations CSOs, farmers' associations and producers' NGOs, is crucial. However, 
the state should stand at an equal distance from these entities and just play the role of arbitrator in case disputes or conflicts arise among these parties. These arrangements demand to review and readjust the current cooperation law or to issue a Prime-Ministerial decree, in coordination with the MALR and other relevant institutions (such as the syndicate of agriculture, the Ministry Local Development, etc...). The role of agricultural cooperatives in the provision of extension services to its members must be enhanced and encouraged, to relief the financial and administrative burden of running this gigantic system of extension. The current conditions are also convenient for trying new mechanisms of contractual extension, through NGOs and farmers' associations, in which farmers will be willing and capable for paying some, or all, of the costs of extension services (El-Shafie, 2009). Again, according to Abdel-Aal (2008) focusing on the important role of agricultural cooperatives in knowledge dissemination will encourage farmers to express their needs.

The investments should be shifted towards a more pluralistic approach with greater inclusion of diversified actors, funding modalities, and creative programs including more focus on business development, knowledge and market information systems, and policy, regulations and legal reforms. The planning and implementation of ICT infrastructure for rural areas must also be an integral part of the National strategy for infrastructure (El-Shafie, et al., 2011).

In order to drow the future directions of EAES, Logical Framework Analysis "LFA" was used. The LFA is a management tool for effective planning and implementation of developmental projects. It provides clear, concise and systematic information on reforming of extension system in Egypt. Information in Table 2 shows the main challenges/issues that are facing the EAES. The analysis came about 16 relevant issues as follows: 1) Renewal and replacement of village field staff, 2) Conduct strategic planning for the extension sector, 3) Improve/reform training at all level of extension work, 4) Upgrade the process of planning and evaluating extension programs, 5) Enhancing participation in the national campaigns of main crops, 6) Technical and administrative independence of the CAAEE, 7) Development of financial resources of CAAEE, 8) The linkage between independent extension and research systems, 9) Creation of M\&E unit in CAEEE, 10) Improve irrigation extension, 11) Improve extension for rural women, 12) Activate the roles of DSCCs, 13) Activate the roles of the extension centers, 14) Maximize utilization of Egypt agriculture channel for communicating extension messages, 15) Modernize extension methods and re-emphasize demonstration fields, and 16) Forming the higher council of agricultural extension

Table 2. Problems, Objectives, and Procedures of Reforming Egyptian Agricultural Extension system

\begin{tabular}{lrll}
\hline Reform Items & \multicolumn{2}{l}{ Problems } & Objectives \\
\hline Renewal & and & Critical declining in & Gradual increase of \\
replacement & of \\
village field staff & numbers of village & village extension agents \\
& & extension agents & $\begin{array}{l}\text { Transformative training } \\
\text { of the potential new } \\
\text { agents }\end{array}$
\end{tabular}

Conduct Strategic Absence of Vision, Devise Vision, Mission planning for the Mission and objectives and objectives for the extension sector of the extension sector

Improve/Reform Training at all level of Extension work

Ineffective/insufficient

Upgrade The process of planning and evaluating Extension programs

Prevailing unclear
concepts and
procedures of planning,
monitoring and
evaluating extension
programs

Enhancing of Egypt training of staff at all levels of extension work.

Absence of updated inclusive training manual extension sector in (MALR)

Build capacities of middle management staff in different Govs. Training newly appointed agents Absence/ambiguity of Integrate an extension

Produce and publish concepts procedures and tools of planning extension programs among the staff and central and local levels Activities/Procedures of Reform

Selection of new agents at basis of $10 \%$ of the current actual numbers in each governorate.

Conduct the Transformative training programs

Present, and discuss different suggested versions for the Vision, Mission and objectives for the extension sector in (MALR)

Conduct training workshops for middle management staff in different Govs.

Gradual planning and implementation of training programs for village staff.

Prepare and publish extension training manual

Review and scrutinize the prevailing planning approaches Conduct workshops to develop skills of planning, monitoring and evaluating extension programs Conduct consultation and 
Participation in the the extension component in the coordination meetings with the

national Campaigns component in the of main Crops

Technical administrative independence of the CAAE

Development of Weak and declining Financial Resources financial resources of of CAAE

The linkage between independent Extension and Research Systems

Creation of $\mathrm{M} \& \mathrm{E}$ unit in CAEE

Improve irrigation Extension
Improve Extension for Rural women
The Extension system Operates under the control of the ARC

Confusion of responsibilities among deputies of ARC for extension and training and that of the Extension sector and the other of CAAE

Absence/ambiguity of the scientific concept of measuring monitoring and socio-economic impacts of Extension activities

Weak culture collective work

Low awareness of the critical situation of water resources

\section{Weak} extension programs directed to rural women

Activate the roles of DSCCs

Deteriorate and weak performance of DSCCs national Campaigns of main Crops and Multiple and duplicate lines of authority and supervision at central and local levels

CAAE

Existence of several extension focused projects with no involvement CAAES
Achieve the Technical and administrative independence of the Central Administration of Agricultural Extension

CAAE

involvement management

Extension projects

Activate inclusion of

Extension component in all MALR projects

Achieve the managerial independence of the extension system

Create technical linkage between ARC and CAEE

Establish mechanisms and manuals for evaluating the educational and socio-economic impacts of Extension Programs

Encourage farmers to form NGO's or association for irrigation water management

Increase awareness on rational use of water resources

Support and upgrade extension programs directed to rural women \{ especially women heads of families)

Upgrade DSCCs in different Govs

Improve in-training authorities in charge of the national Campaigns of main Crops

Apply the scientific concepts of planning, implementing, monitoring and evaluating educational impacts of campaigns

Issue ministerial decree to separate

(CAAE) from (ARC)

Institutionalize the technical and supportive relationship between (CAAE) and (ARC)

Inventory all extension projects in the ministry

Support extension component in all production and marketing projects

Introduce new approaches to activate extension services (Contractual, cost recovery for specific services)

Design independence mechanisms of CAEE at all levels

Design Linkage mechanisms between ARC and CAEE at Central and local levels

Training the staff of CAEE on methods of mentoring and evaluation

Prepare manuals on mentoring and evaluation of Extension activities

Provide farmers with technical assistance to establish and run their water associations

Design and implement awareness campaigns on rational use of water

Plan, implement, monitor and evaluate extension programs directed rural women and girls in different govs. Limited or absent implement, monitor and evaluate In Service Training programs for DSCCs staff 


\begin{tabular}{|c|c|c|c|}
\hline \multirow{4}{*}{$\begin{array}{l}\text { Activate the roles of } \\
\text { the extension Centers }\end{array}$} & $\begin{array}{l}\text { service training of } \\
\text { SCCs staff }\end{array}$ & $\begin{array}{l}\text { service training for the } \\
\text { staff }\end{array}$ & \\
\hline & $\begin{array}{l}\text { Deteriorating and weak } \\
\text { performance of the } \\
\text { Extension centers }\end{array}$ & $\begin{array}{l}\text { Upgrade Extension } \\
\text { centers (220) in Govs. } \\
\text { Improve in-training }\end{array}$ & $\begin{array}{l}\text { Prepare plans to activate the } \\
\text { roles of the extension Centers } \\
\text { Plan, implement, monitor and }\end{array}$ \\
\hline & $\begin{array}{l}\text { Lack of necessary } \\
\text { funds to run activities }\end{array}$ & $\begin{array}{l}\text { service training for the } \\
\text { staff }\end{array}$ & $\begin{array}{l}\text { evaluate In- Service Training } \\
\text { programs for DSCCs staff }\end{array}$ \\
\hline & $\begin{array}{l}\text { Limited or absent } \\
\text { in-service training of } \\
\text { DSCCs staff }\end{array}$ & & \\
\hline Modernize Extension & Absence/unclear & Introduce & Introduce \\
\hline $\begin{array}{l}\text { Methods and } \\
\text { re-emphasize }\end{array}$ & $\begin{array}{l}\text { concepts related to } \\
\text { utilization of Extension }\end{array}$ & $\begin{array}{l}\text { extension methods } \\
\text { Spread utilizing Demo }\end{array}$ & $\begin{array}{l}\text { methods and activate food and } \\
\text { value chains }\end{array}$ \\
\hline ation fields & $\begin{array}{l}\text { methods and } \\
\text { demonstration fields }\end{array}$ & fields for main crops & $\begin{array}{l}\text { Expand using Demo fields with } \\
\text { farmers participation }\end{array}$ \\
\hline $\begin{array}{l}\text { Maxim } \\
\text { of Egy }\end{array}$ & $\begin{array}{l}\text { Insufficient material for } \\
\text { transmission }\end{array}$ & $\begin{array}{l}\text { Provide the channel with } \\
\text { experienced staff. }\end{array}$ & $\begin{array}{l}\text { Provide assistance to the staff to } \\
\text { plan, implement and evaluate }\end{array}$ \\
\hline $\begin{array}{l}\text { Channel for } \\
\text { communicating } \\
\text { Extension messages }\end{array}$ & $\begin{array}{l}\text { Repeating broadcasting } \\
\text { Programs during the } \\
\text { day (lack of material) }\end{array}$ & $\begin{array}{l}\text { Provide the technical } \\
\text { assistance } \\
\text { Increase the coverage of } \\
\text { the channel }\end{array}$ & $\begin{array}{l}\text { programs for upgrading } \\
\text { performance of the channel }\end{array}$ \\
\hline $\begin{array}{l}\text { Forming the Higher } \\
\text { Council } \\
\text { Agricultural } \\
\text { Extension }\end{array}$ & $\begin{array}{l}\text { Multiple supervising } \\
\text { bodies on Agricultural } \\
\text { Extension }\end{array}$ & Unify supervising bodies & $\begin{array}{l}\text { Form higher national Council for } \\
\text { Agricultural } \\
\begin{array}{l}\text { Extension } \\
\text { Regional } \\
\text { councils }\end{array} \\
\text { governorates. }\end{array}$ \\
\hline
\end{tabular}

Source: developed by authors

\section{References}

Abdel-Aal, M. H. (2008). Farmers and globalization in Egypt. International Journal of Public Affairs, 4, 27-42.

Abdel-Ghany, M. M. M. (2014). Readiness for change, change beliefs and resistance to change of extension personnel in the New Valley governorate about mobile extension. Annals of Agricultural Sciences, 59(2), 297-303. https://doi.org/10.1016/j.aoas.2014.11.019

Abdel-Ghany, M. M. M. (2015). Farmers' Behavioral Intentions to Use Mobile Extension in Assiut Governorate, Arab Univ. J. Agric. Sci., 23(2), 439-448. https://doi.org/10.21608/ajs.2015.14586

Abdel-Ghany, M. M. M., \& Diab, A. M. (2013). Reforming agricultural extension in Egypt from the viewpoint of central level extension employees. Arab Univ. J. Agric. Sci., 21(2), 143-154. https://doi.org/10.21608/ajs.2013.14816

Abdel-Ghany, M. M. M., \& Diab, A. M. (2015). Measuring Agricultural Extension Service Quality in Nubaria Region Using Total Quality and Service Quality Scales. Journal of Agricultural Economics and Social Sciences, 6(11), 1737-1750. https://doi.org/10.21608/jaess.2015.41775s

Abdelhakam, A. M. (2005). Agricultural Extension in Egypt. Regional Workshop on Options of Reform for Agricultural Extension in the Near East. Amman, Jordan 2-4 October, Food and Agriculture Organization of the United Nations Regional Office for the Near East, Cairo. pp. 22-26.

Abdel-Hamid, K. M. (1998) Agricultural research systems in Egypt with an emphasis on the Agricultural Research Center (ARC). In: Plaza P. (Ed.), Regionalization of agricultural research in the Mediterranean and Near-East countries (pp. 44-55). Montpellier: CIHEAM, (Cahiers Options Méditerranéennes; n. 32).

Abdou, D. K., ElEraki, M., AlNagar, K., \& Sholkamy, M. (ND). Reforming the Agricultural Extension Services in Egypt: The Case of the Farmers Field Schools in Qena. Egypt Network for Integrated Development (ENID). Policy Brief 029.

Al-Sawwaf, M. (1992). Studying the Effectiveness of Performance Proficiency Reports in Government Departments in Sohaj. King Abdul Aziz. Military Academy Magazine, 1413(23), 110-111.

Al-Waqa'i al-Misriyya "Official Egyptian newspaper". (2016). Law no. 81 on Civil Service. No. 43-a. November 
(In Arabic).

Anandajayasekeram, P., Puskur, R., Workneh, S., \& Hoekstra, D. (2008). Concepts and practices in agricultural extension in developing countries: A source book. IFPRI (International Food Policy Research Institute), Washington, DC, USA, and ILRI (International Livestock Research Institute), Nairobi, Kenya. pp. 275.

Anon (2008). Case Study: Institution-Based Information Systems, Egypt. National Agricultural Research Information Management System (NARIMS). CIRAD, pp. 8.

CAAEE. (2018a). The official website of the Central Administration for Agricultural Extension and Environment. Retrieved from http://www.caaes.org/

CAAEE. (2018b). Extension personnel in Egypt. Unpublished statistics. Central Administration for Agricultural Extension and Environment. The Technical office.

CAAEE. (2019). Agricultural extension centers. Central Administration for Agricultural Extension (in Arabic). Retrieved from http://www.caaes.org/posts/591586

CAPMAS. (2018). Central Agency for public mobilization and statistics. Retrieved from https://www.capmas.gov.eg/HomePage.aspx

Diab, A. M. (2017). Designing an Index for Criteria of the Organization's Quality Assurance in Agricultural Extension in Egypt (ORGAQUALEX). Journal of Agricultural Economics and Social Sciences, 8(4), 189-194. https://doi.org/10.21608/jaess.2017.36473

Diab, A. M. (2017). Readability of some Egyptian agricultural magazines. Journal of Agricultural Economics and Social Sciences, 8(3), 173-179. https://doi.org/10.21608/jaess.2017.36467

Diab, A. M., \& Abdel-Rahman, Z. M. (2016). Willingness of Egyptian Agricultural Extension Middle Level Managers to Use Cell Phones in Extension Services. Arab Univ. J. Agric. Sci., 24(2), 453-464. https://doi.org/10.21608/ajs.2016.14343

Diab, A. M. (2018). Designing an Index for Criteria of the Management Quality Assurance in Agricultural Extension in Egypt (MANQUALEX). Journal of Agricultural Economics and Social Sciences.

Diab, A. M. (2018). Designing an Index for Criteria of the Service Quality Assurance in Agricultural Extension in Egypt (SERVQUALEX). Journal of Agricultural Economics and Social Sciences.

Diab, A. M., \& Abdel-Ghany, M. M. (2014). A study of work environment and competencies necessary for agricultural extension in Egypt using Delphi technique. Journal of Agricultural Economics and Social Sciences, 5(5), 789-800. https://doi.org/10.21608/jaess.2014.42203

El-Shafie, E. (2009). Improving agricultural extension in Egypt, a need for new institutional arrangements. 19th European Seminar on Extension Education, Theory and practice of advisory work in a time of turbulences, 15 - 19 September, Assisi (Perugia), Italy.

El-Shafie, E. M., El-Sharief, Z. H., \& Diab, A. M. (2011). Fostering Agricultural Innovation System of Egypt. 20th European Seminar for Extension Education. Private-public partnerships for advisory services in Europe (30 August: 3 September), JTO School of Management, Kirkkonummi, Finland. pp. 86-90.

FAO. (2017). FAO achievements in Egypt: 1978-2016, FAO representation office in Egypt.

Kumara, B., \& Geetha, M. (2016). Extension Services in Agriculture Sector. International Journal of Research and Scientific Innovation (IJRSI), 3(8), 166-170.

Maher, A. (2011). Reforming Government Employees Performance Appraisal System in New Egypt (After the 25th January Revolution). Journal of Emerging Trends in Economics and Management Sciences (JETEMS), 2(5), 399-401.

MALR. (2009). A strategy for sustainable agricultural development up to 2030. Ministry of Agriculture and Land Reclamation, Agricultural Research and Development Council.

Marzin, J., Bonnet, P., Bessaoud, O., \& Ton-Nu, C. (2017). Study on Small-Scale Family Farming in the Near East and North Africa Region. FAO, CIRAD and CIHEAM.

Qamar, M. K. (2005). Modernizing national agricultural extension systems: a practical guide for policy-makers of developing countries. Research, Extension and Training Division. Sustainable Development Department. Food and Agriculture Organization of the United Nations, Rome, Italy.

Rivera, W. M., Qamar, M. K., \& Mwandemere, H. K. (2005). Enhancing Coordination among AKIS/RD Actors: 
An Analytical Comparative Review of Country Studies on Agricultural Knowledge and Information Systems for Rural Development (AKIS/RD). FAO, Rome.

Rivera, W., El-Shafie, E. M., \& Aboul-Seoud, K. H. (1997). The public sector agricultural extension system in Egypt: a pluralistic complex in transition, Journal of International Agricultural and Extension Education, 4(3), 67-74. https://doi.org/10.5191/jiaee.1997.04307

Rivera, W. M., \& Qamar, M. K. (2003). Agricultural Extension, Rural Development and the Food Security Challenge. Food and Agriculture Organization of the United Nations, Rome.

Scoullar, B. B. (1994). Consultancy report on agricultural extension training and leadership development: strengthening the national agricultural extension systems. Technical cooperation program document, TCP/EGY/2355(T), FAO, Rome.

Shaker, M., Farid, M., \& Saed, A. (2003). Agricultural extension centers, the current situation and future needs, The Sixth Conference of the Agricultural Extension and Rural Development, National Dialogue Programme in the Field of Agricultural Extension Work. University of Mansoura, Faculty of Agriculture, Center of Agricultural Extension and Advisory Services, In collaboration with the University of Guelph, Faculty of Agriculture, Department of Rural Extension Studies, Ontario, Canada.

Shalaby, M. Y., Al-Zahrani, K. H., Baig, M. B., Straquadine, G. S., \& Aldosari, F. (2011). Threats and challenges to sustainable agriculture and rural Development in Egypt: implications for agricultural extension. Journal of Animal and Plant Sciences, 21(3), 581-588.

Swanson, B. E., Bentz, R. P., \& Sofranko, A. J. (1997). Improving agricultural extension: A reference manual. Food and Agriculture Organization of the United Nations, Rome.

USAID. (2017). Agriculture, Egypt fact sheet.

Vodafone Egypt. (2011). Vodafone launches agricultural guidance services via mobile. Retrieved from http://www.vodafone.com.eg/vodafoneportalWeb/en/releaseDetail_Page?dDocName=VF_017939

Zahran, Y. (1998). The training manual introduction for the basics of rural extension work, The training manual for the basics of rural extension work. Egyptian Ministry of Agriculture and Land Reclamation, The Central Administration for Agricultural Extension, Part 1, In collaboration with the University of Guelph, Faculty of Agriculture, Department of Rural Extension Studies, Ontario, Canada.

\section{Copyrights}

Copyright for this article is retained by the author(s), with first publication rights granted to the journal.

This is an open-access article distributed under the terms and conditions of the Creative Commons Attribution license (http://creativecommons.org/licenses/by/3.0/). 